\title{
Efektivitas Penerapan Sistem Informasi Akuntansi, Kecanggihan Teknologi, Internal Locus Of Control dan Kinerja Pegawai
}

\author{
Ni Made Kusuma Devi ${ }^{1}$ \\ Fakultas Ekonomi dan Bisnis \\ Universitas Udayana, Indonesia
}

\author{
Ida Bagus Dharmadiaksa ${ }^{2}$ \\ Fakultas Ekonomi dan Bisnis \\ Universitas Udayana, Indonesia
}

\begin{abstract}
Surel : kusumadevimia9@gmail.com
\section{ABSTRAK}

Penelitian ini bertujuan untuk menganalisa dan menguji secara empiris pengaruh efektivitas penerapan sistem informasi akuntansi, teknologi informasidaninternal locus of controlpada kinerja pegawai Inspektorat Provinsi Bali. Penelitian ini menggunakan nonprobability sampling yaitu metode purposive sampling dengan kriteria pegawai yang menggunakan sistem informasi akuntansi dan menggunakan perangkat komputer dalam menjalankan aktivitas pekerjaannya. Kuesioner dibagikan langsung kepada pegawai dengan teknik analisis yang digunakan adalah regresi linear berganda. Berdasarkan hasil analisis menunjukan bahwa efektivitas penerapan sistem informasi akuntansi, teknologi informasidaninternal locus of control berpengaruh positif dan signifikan pada kinerja pegawai.
\end{abstract}

Kata Kunci: Efektivitas Penerapan Sistem Informasi Akuntansi; Teknologi Informasi; Internal Locus Of Control; Kinerja Pegawai.

\section{Effectiveness of Accounting Information System Implementation, Technological Sophistication, Internal Locus Of Control and Employee Performance}

\begin{abstract}
This study aims to analyze and empirically test the effect of the effectiveness of the application of accounting information systems, information technology and internal locus of control on the performance of the Bali Provincial Inspectorate employees. This study uses nonprobability sampling, namely purposive sampling method with the criteria of employees who use accounting information systems and use computers in carrying out their work activities. Questionnaires were distributed directly to employees with the analytical technique used was multiple linear regression. Based on the analysis results show that the effectiveness of the application of accounting information systems, information technology and internal locus of control has a positive and significant effect on employee performance.

Keywords: Effectiveness Of The Application Of Accounting Information Systems; Information Technolog; Internal Locus Of Control; Employee Performance.
\end{abstract}

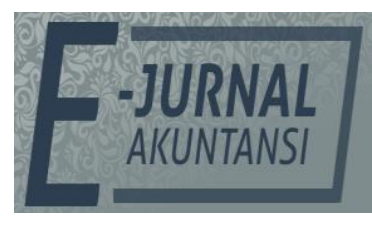

e-ISSN 2302-8556

Vol. 31 No. 6

Denpasar, Juni 2021

Hal. 1438-1450

DOI:

10.24843/EJA.2021.v31.i06.p07

PENGUTIPAN:

Devi, N.M.K., \&

Dharmadiaksa, I.B. (2021).

Efektivitas Penerapan Sistem Informasi Akuntansi,

Kecanggihan Teknologi, Internal Locus Of Control dan

Kinerja Pegawai. E-Jurnal

Akuntansi, 31(6), 1438-1450

RIWAYAT ARTIKEL:

Artikel Masuk:

26 April 2021

Artikel Diterima:

16 Juni 2021

Artikel dapat diakses: https:/ / ojs.unud.ac.id/index.php/Akuntansi/index 


\section{PENDAHULUAN}

Pesatnya perkembangan teknologi dengan berbasis komputer dapat mengefisiensi waktu dalam menginput data atau informasi lainnya untuk selanjutnya diolah menjadi output yang dapat mendukung pengambilan keputusan yang dapat diandalkan. Menurut (Imam, 2012) sistem informasi akuntansi merupakan bagian yang sangat penting dalam suatu sistem informasi yang dapat menerima data mentah keuangan dan mengolahnya menjadi suatu informasi untuk kepentingan luar dan dalam di suatu organisasi. (Krahel \& Vasarhelyi, 2014) menyatakan bahwa metode manual yang digunakan tidak efektif karena memerlukan waktu yang lebih untuk melakukan perhitungan ulang dari awal jika terjadi kesalahan dan perubahan data untuk menghasilkan suatu laporan keuangan. Banyak perusahaan maupun instansi menerapkan sistem informasi akuntansi yang berbasis teknologi.

Sistem informasi akuntansi untuk kantor pemerintahan menerapkan sistem informasi akuntansi pemerintahan. Sistem informasi akuntansi pemerintahan merupakan kumpulan komponen peralatan dan manusia (sumber daya) dari organisasi pemerintah untuk melakukan pengolahan (mengumpulkan, mencatat, menyimpan, dan mengolah) peristiwa/data keuangan pemerintahan untuk menghasilkan informasi bagi pengambil keputusan (pengguna). Salah satu komponen yang menunjang SIA pemerintahan adalah software Sistem Informasi Pengelolaan Keuangan Daerah (SIPKD) dan E-plan. Akhir tahun 2020 diperkenalkannya sistem baru bernama Sistem Informasi Pengelolaan Daerah (SIPD). SIPD ini sudah mencangkup kedua sistem SIPKD dan E-plan, sehingga bila terjadinya suatu koreksi maka sistem SIPD dengan otomatis tersingkronisasi antara perencanaan dan rician anggaran yang akan dikoreksi.

Alasan dipilihnya Inspektorat Provinsi Bali sebagai lokasi penelitian adalah Inspektorat Provinsi Bali merupakan lembaga pemerintahan yang sangat unik karena selain mengeksekusi anggaran dan membuat pelaporan Inspektorat Provinsi Bali juga bertugas sebagai auditor internal pemerintah daerah. Inspektorat bertugas sebagai auditor internal pemerintah yang memeriksa atau mengaudit laporan keuangan yang dihasilkan oleh OPD yang ada di Bali, maka dari itu pemahaman akan SIPD ini penting dimiliki oleh pegawai pengguna sistem informasi akuntansi di Inspektorat Provinsi Bali.

Penelitian (Goodhue \& Thompson, 1995) menyatakan, pencapaian kinerja individual dinyatakan berkaitan dengan pencapaian serangkaian tugas-tugas individu dengan dukungan teknologi informasi yang ada, sehingga diharapkan dengan dukungan teknologi informasi, kinerja individu dapat memberikan hasil yang baik dari segi kualitas, kuantitas, waktu pengerjaan, disiplin kerja, dan mau bekerjasama. Kinerja pegawai Inspektorat provinsi bali dapat dipengaruhi oleh beberapa faktor. Menurut pegawai sub bagian keuangan Inspektorat Provinsi Bali, I Putu Wira Pramana, permasalahan yang dihadapi pegawai pengguna sistem informasi berbasis teknologi pada Inspektorat Provinsi Bali yaitu, terjadinya kesalahan dalam proses penginput data laporan anggaran saat menggunakan sistem SIPKD dan E-plan. Proses untuk menginput data tersebut masih dilakukan secara manual. Saat hendak memerbaiki kesalahan dalam penginputan data tersebut pegawai harus melakukan koreksi pada instansi terkait dalam hal ini apabila kesalahan terjadi pada proses perencanaan 
anggaranmaka inspektorat harus melakukan koreksi kepadaBappeda dan sebaliknya apabila kesalahan terjadi pada proses perincian anggaran maka inspektorat harus melakukan koreksi kepada BPKAD.

Permasalahan lainnya, terjadi keterlambatan penyelesaian laporan anggaran yang dilakukan oleh pegawai pemakai sistem SIPD ini karena sistem ini menggunakan tenggat waktu dalam menyelesaikan anggaran. Hal ini dapat terjadi karena kurang efisiennya penggunaan waktu pegawai dalam menyelesaikan pekerjaanya yang tidak sesuai dengan tenggat waktu yang diberikan. Pergantian sistem yang baru diterapkam mengakibatkan masih kurang fasihnya pegawai dalam menggunakan sistem ini. Keterlambatan penyelesaian laporan anggaran dapat berakibat fatal, apabila pegawai tidak dapat menyelesaikan anggaran tepat pada waktunya, dapat berkibat instansi gagal mendapatkan anggaran untuk melaksanakan suatu kegiatan, tetapi apabila dalam keadaan mendesak instansi dapat memperpanjang waktu dalam proses penganggaran selama satu hari kepada instansi terkait untuk kemudian akan di koordinasikan dengan pusat di Kemendagri. (Inspektorat 23/11/20, 12:36)

TAM (Technology Acceptance Model), pertama kali diperkenalkan oleh (Davis, 1989). Model TAM merupakan sebuah aplikasi dan pengembangan dari Theory of Reasoned Action (TRA) yang menjelaskan mengenai penggunaan sistem teknologi informasi yang digunakan untuk menjelaskan penerimaan individual terhadap penggunaan sistem informasi. Model TAM menjelaskan mengenai penggunaan sistem teknologi informasi yang akan dipengaruhi oleh variabel kemanfaatan (usefulness) dan variabel kemudahan pemakaian (ease of use). Model ini menyebutkan bahwa pengguna sistem informasi cenderung menggunakan sistem apabila sistem tersebut mudah digunakan dam memberikan manfaat.

Sistem informasi akuntansi adalah kumpulan sub-sub sistem atau komponen-komponen baik fisik maupun non fisik yangsaling berhubungan secara harmonis untukmengolah data keuangan menjadi informasi keuangan (Marjulin, 2019). Peningkatan kinerja individu tidak akan tercapai jika penerapan sistem informasi yang tidak sesuai dengan kebutuhan pemakai (Indralesmana \& Suaryana, 2014). (Salehi et al., 2010) menyatakan bahwa tujuan SIA adalah untuk melakukan proses pengolahan transaksi dan informasi. SIA penting diterapkan dalam organisasi dalam rangka menunjang peningkatan efisiensi organisasi dan dapat menimbulkan daya saing dengan tersedianya informasi kauangan yang dapat mendukung pengambilan keputusan(Al-Eqab; Adel, 2013).

(Hussein et al, 2007) kecanggihan teknologi informasi merefleksikan keanekaragaman jumlah teknologi yang digunakan sedangkan kecanggihan informasi ditandai oleh sifat portofolio penerapannya. Teknologi informasi ini harus diimbangi dengan SDM yang mengerti dan paham akan penggunaan teknologi tersebut. (Ratnaningsih \& Suaryana, 2014) menjelaskan bahwa teknologi informasi di masa kini memiliki perkembangan yang pesat bahkan mampu menghasilkan beraneka ragam teknologi sistem yang dirancang untuk membantu pekerjaan manusia dalam menghasilkan kualitas informasi terbaik. (Sumardiyanti, 1999) mengungkapkan bahwa organisasi/instansi menanamkan investasi yang besar untuk mengevaluasi kinerja individual atau organisasi berkaitan dengan implementasi teknologi dalam suatu sistem informasi untuk mengukur keberhasilan suatu sistem secara ekstrem sulit dilakukan. Menurut 
(Ismail \& King, 2007), instansi yang memiliki kecanggihan teknologi informasi akan memiliki tingkat keselarasan sistem informasi akuntansi yang baik dibandingkan dengan instansi yang tidak menggunakan teknologi informasi.

(Leach-Lopez, 2013) menyatakan bahwa locus of control merupakan suatu pembangunan kepribadian dari seorang individual. (Brownell, 1981) membagi locus of control menjadi dua, yakni internal locus of control dan external locus of control. internal locus of control adalah keyakinan seorang individu bahwa mereka memegang kendali atas peristiwa-peristiwa yang mereka alami. Menurut(Wang \& Newlin, 2000) individu dengan internal LOC memiliki orientasi untuk bekerja lebih baik, memiliki tingkat kepuasan kerja yang tinggi dan rata-rata kemalasan yang lebih rendah dibanding individu dengan lokus kendali eksternal.

Berdasarkan penelitian terdahulu, masih terdapat perbedaan-perbedaan hasil penelitian. (Suratini et al., 2015) mengungkapkan bahwa efektivitas sistem informasi akutansi danpenggunaan teknologi informasi akuntansi berpengaruh padakinerja individual. Sejalan dengan penelitian yang dilakukan oleh (Awosejo, et al, 2013) menyatakan bahwa efektivitas penggunaan berpengaruh positif pada kinerja individual pengguna SIA. Namun, Soudani (2012) menemukan hasil yang berbeda dan mendapatkan hasil bahwa tidak mendukung adaya hubungan yang positif antara sistem informasi akuntansi pada kinerja individu.

TAM mendukung variabel efektivitas penerapan sistem informasi akuntansi dengan menyatakan bahwa penggunaan sistem informasi akan meningkatkan kinerja pegawai dan penggunaan sistem informasi akan membantu pemakai dalam menyelesaiakan suatu pekerjaan (Gupta et al., 2007) Hasil penelitian (Anjani Dewantari \& Putra, 2019) serta (D. P. A. D. Putra \& Ratna Sari, 2018) menyatakan bahwa efektivitas penerapan sistem informasi akuntansi berpengaruh positif pada kinerja pegawai. Sejalan dengan penelitian (Sugiantara \& Putra, 2017) yang menyatakan bahwa salah satu faktor yang memengaruhi kinerja pegawai Dispenda Kota Denpasar adalah efektivitas penerapan sistem informasi akuntansi.

$\mathrm{H}_{1}$ : Efektivitas penerapan sistem informasi akuntansi berpengaruh positif pada kinerja pegawai.

TAM menyatakan bahwa ketika terdapat terdapat suatu teknologi baru, maka penggunaan teknologi akan dihadapkan oleh faktor-faktor yang memengaruhi individu untuk menggunakan teknologi tersebut salah satunya kinerja pegawai itu sendiri.Hasil penelitian yang dilakukan oleh (I. M. Putra et al., 2017) serta (Dewi \& Dharmadiaksa, 2019) menghasilkan bahwa kecanggihan teknologi informasi memiliki pengaruh signifikan dengan kinerja individu.Serupa dengan itu, Penelitian (Kinarwanto, 2013) menyatakan bahwa menyatakan bahwa pemanfaatan teknologi informasi berpengaruh positif pada kinerja individual.

$\mathrm{H}_{2}$ : Teknologi informasi berpengaruh positif pada kinerja pegawai

TAM menyatakan bahwa penerimaan pengguna atas penerapan sistem informasi didasarkan pada dua persepsi, yaitu persepsi kebermanfaatan dan persepsi kemudahan. Bedasarkan kedua persepsi tersebut, semakin seseorang memiliki keyakinan di dalam dirinya bahwa sistem informasi yang digunakan medatangkan kemudahan dan manfaat, maka akan semakin besar penerimaan penerapan sistem informasi tersebut, dimana Internal locus of control menjelaskan 
mengenai keyakinan individu atas apa yang terjadi merupakan akibat dari perbuatan yang terlah dilakukan. Berdasarkan dari hasil penelitian (D. P. A. D. Putra \& Ratna Sari, 2018) serta (Nainggolan et al., 2018) meperoleh hasil mendukung teori diatas, bahwa internal locus of control berpengaruh positif pada kinerja pegawai, sejalan dengan penelitian yang dilakukan oleh (Rahayu \& Badera, 2017) yang juga menyatakan bahwa internal locus of control berpengaruh positif pada kinerja individual.

$\mathrm{H}_{3}$ : Internal locus of control berpengaruh positif pada kinerja pegawai

\section{METODE PENELITIAN}

Penelitian ini menggunakan pendekatan kuantitatif yang bersifat asosiatif. Penelitian ini dilakukan pada Kantor Inspektorat Provisi Bali. Objek padapenelitian ini adalah kinerja pegawai. Variabel bebas yang digunakan dalam penelitian ini adalah efektifitas sistem informasi akuntansi (X1), teknologi informasi (X2) dan internal locus of control (X3), varibel terikatnya adalah kinerja pegawai (Y). Kuesioner dalam penelitian ini langsung diantarakan ke lokasi penelitian untuk diberikan kepada responden. Pengukuran masing-masing variabel dilakukan dengan menggunakan kuesioner skala Likert dengan skala yang digunakan yaitu skala 5 poin.

Adapun indikator pengukuran efektivitas penerapan sistem informasi akuntansi pada penelitian (Turnip \& Suardhika, 2018): Fleksibilitas, kemudahan pengguna, sistem realibilitas. (Sari, 2017) menyatakan bahwa teknologi informasi merupakan suatu teknologi yang menitikberatkan penggunaan komputer dan teknologi yang berhubungan dengan pengaturan sumber informasi. Locus of control merupakan cara pandang seseorang teradap suatu peristiwa, apakah seseorang merasa dapat atau tidak mengendalikan peristiwa yang terjadi padanya (Rotter, 1966). Indikator pengukuran variabel internal locus of control diadopsi dari penelitian (Kusnadi \& Suputhra, 2015), yaitu: kemampuan, minat, usaha. Kinerja pegawai ini mengacu pada pencapaian tugas-tugas dengan adanya bantuan dan dukungan dari suatu teknologi yang tersedia, sehingga tugas yang dikerjakan dapat diselesaikan dengan cepat (Alannita \& Suaryana, 2014).

Metode penentuan sampel yang digunakan dalam penelitian ini adalah non probability sampling yaitu dengan teknik purposive sampling yang merupakan teknik penentuan sampel penelitian dengan beberapa pertimbangan atau kriteria tertentu. Populasi dalam penelitian ini adalahpegawai Inspektorat Provinsi Bali. Responden yang digunakan sebagai sampel dalam penelitian ini yaitu dari 144 pegawai yang ada di Inspektorat Provinsi Bali, diambil sampel sebanyak 76 orang. Kriteria pengambilan sampel yaitu pegawai Inspektorat Provinsi Bali yang menggunaan SIA dan perangkat komputer dalam menjalankan pekerjaannya. Metode pengumpulan data yang dilakukan dalam penelitian ini adalah metode pengumpulan data primer dengan menggunakan pertanyaan atau pernyataan tertulis berupa kuesioner atau angket terkait dengan variabel yang diteliti.Instrumen yang digunakan dianalisis validitas dan reliabilitas, kemudian dilakukan uji statistik deskriptif, uji asumsi klasik dan regresi linier berganda. 


\section{HASIL DAN PEMBAHASAN}

Berdasarkan uji validitas menunjukan bahwa seluruh item pertanyaan dalam variabel efektivitas penerapan sistem informasi akuntansi, teknologi informasi, internal locus of control dan kinerja pegawai lebih besar dari 0,3 sehingga seluruh indikator tersebut telah memenuhi syarat validitas data. Hasil uji reliabilitasmenunjukan bahwa seluruh instrumen penelitian memiliki koefisien Cronbach's Alpha lebih dari 0,60Hal ini menunjukkan bahwa, semua instrument reliabilitas sehingga dapat digunakan untuk melakukan penelitian.

Berdasarkan hasil uji normalitas Kolmogorov Smirnov sebesar 0,209, sedangkan nilai Asymp. Sig. (2-tailed) sebesar 0,063. Hasil tersebut mengidentifikasikan bahwa model regresi tesebut bedistribusi normal dikarenakan nilai Asymp. Sig. (2-tailed) sebesar 0,063 lebih besar dari pada nilai alpha 0,05 . Hasil dari uji multikoleniaritas menunjukan bahwa nilaitolerance untuk setiap variabel memiliki nilai lebih besar dari $10 \%$ atau $(0,10)$ dan nilai VIF lebih kecil dari 10. Maka uji multikoleniaritas pada penelitian ini menunjukan bahwa model regresi bebas dari multikoleniaritas. Hasil dari uji heteroskedastisitas menunjukan bahwa nilai Sig dari setiap variabel lebih besar dari 0,05 yang diartikan bahwa tidak terdapat pengaruh antara variabel bebas dengan absolute residual. Maka model pada penelitian ini bebas dari gejala heteroskedastisitas.

Tabel 1. Hasil Analisis Regresi Linier Berganda

\begin{tabular}{|c|c|c|c|c|c|}
\hline \multirow[t]{2}{*}{ Model } & \multicolumn{2}{|c|}{$\begin{array}{l}\text { Unstandardized } \\
\text { Coefficients }\end{array}$} & \multirow{2}{*}{$\begin{array}{c}\text { Standardized } \\
\text { Coefficients }\end{array}$} & \multirow[t]{2}{*}{$t$} & \multirow[t]{2}{*}{ Sig. } \\
\hline & B & Std. Error & & & \\
\hline (Constant) & 0,343 & 0,222 & & 1,549 & 0,126 \\
\hline Efektivitas Penerapan & 0,241 & 0,100 & 0,259 & 2,413 & 0,018 \\
\hline $\begin{array}{l}\text { Sistem Informasi Akuntansi } \\
(\mathrm{X} 1)\end{array}$ & & & & & \\
\hline Teknologi Informasi (X2) & 0,289 & 0,145 & 0,298 & 1,994 & 0,050 \\
\hline Internal Locus Of Control(X3) & 0,379 & 0,136 & 0,385 & 2,782 & 0,007 \\
\hline
\end{tabular}

Sumber: Data Penelitian, 2021

Berdasarkan hasil analisis regresi linier berganda pada Tabel 1, maka dapat disusun persamaan regresi sebagai berikut:.

$$
\mathrm{Y}=0,343+0,241 \mathrm{X}_{1}+0,289 \mathrm{X}_{2}+0,379 \mathrm{X}_{3}
$$

Hasil analisis yang telah dilakukan makainterpretasi dari persamaan regresi diatas dapat dijelaskan sebagai berikut:Nilai koefisien regresi efektivitas penerapan sistem informasi akuntansi $\left(X_{1}\right)$ sebesar 0,343 memiliki arti efektivitas penerapan sistem informasi akuntansi berpengaruh positif terhadap kinerja pegawai $(Y)$ di Inspektorat Provinsi Bali, dengan signifikasi $X_{1}$ lebih kecil dari $0,05(0,018<0,05)$.Nilai koefisien regresi teknologi informasi $\left(X_{2}\right)$ sebesar 0,241 memiliki arti teknologi informasi berpengaruh positif terhadap kinerja pegawai (Y) di Inspektorat Provinsi Bali, dengan signifikasi $X_{2}$ sama dengan 0,05 (0,05= 0,05).Nilai koefisien regresi internal locus of control $\left(X_{3}\right)$ sebesar 0,379 memiliki arti internal locus of control berpengaruh positif terhadap kinerja pegawai $(\mathrm{Y}) \mathrm{di}$ Inspektorat Provinsi Bali, dengan signifikasi $X_{1}$ lebih kecil dari 0,05 $(0,007<0,05)$.

Berdasarkan hasil analisis pengaruh efektivitas penerapan sistem informasi akuntansi pada kinerja pegawai memiliki nilai koefisien beta sebesar 0,241 hal ini menunjukkan bahwa efektivitas penerapan sistem informasi akuntasi 
berpengaruh positif terhadap kinerja pegawai. Nilai signifikansi pada variabel $X_{1}$ terhadap $\mathrm{Y}$ adalah sebesar 0,018 lebih kecil dari 0,05 mengindikasikan bahwa $\mathrm{H}_{0}$ ditolak dan $\mathrm{H}_{1}$ diterima, yang berarti terdapat pengaruh signifikan antara efektifitas penerapan sistem informasi akuntansi $\left(\mathrm{X}_{1}\right)$ pada kinerja pegawai $(\mathrm{Y})$.

Berdasarkan hasil analisispengaruh teknologi informasipada kinerja pegawai memiliki nilai koefisien beta sebesar 0,289 hal ini berati bahwa teknologi informasi berpegaruh positif terhadap kinerja pegawai. Nilai signifikansi variabel $\mathrm{X}_{2}$ adalah sebesar 0,05sama dengan taraf signifikansinya yang mengindikasikan $\mathrm{H}_{0}$ ditolak dan $\mathrm{H}_{2}$ diterima, maka ini berati bahwa terdapat pengaruh signifikan antara teknologi informasi $\left(\mathrm{X}_{2}\right)$ pada kinerja pegawai $(\mathrm{Y})$.

Berdasarkan hasil analisisInternal locus of control pada kinerja pegawai memiliki nilai koefisien beta sebesar 0,379 hal ini berati Internal locus of control berpengaruh positif terhadap kinerja pegawai. Nilai signifikansi $X_{3}$ adalah sebesar 0,007 lebih kecil dari 0,05 mengindikasikan $\mathrm{H}_{0}$ ditolak dan $\mathrm{H}_{3}$ diterima. Hal ini berati bahwa terdapat pengaruh signifikan antara Internal locus of controlpada kinerja pegawai.

Koefisien determinasi $\left(\mathrm{R}^{2}\right)$ digunakan untuk mengetahui atau mengukur kemampuan model dalam menerangkan variasi variabel independen. Menggunakan nilai adjusted $\mathrm{R}^{2}$ untuk mengevaluasi model regresi yang terbaik, nilai koefisien determinasi yang rendah dapat dikatakan kemampuan variabel independen dalam menjelaskan variasi variabel dependen sangat terbatas, sedangkan jika nilai koefisien determinasi yang tinggi dapat dikatakan kemampuan variabel independen dalam memberikan semua informasi yang dibutuhkan untuk memerhitungkan variasi variabel dependen.

Tabel 2. Hasil Analisis Koefisien Determinasi $\left(\mathbf{R}^{2}\right)$

\begin{tabular}{|c|c|c|c|c|}
\hline Model & $\mathrm{R}$ & R Square & Adjusted R Square & $\begin{array}{l}\text { Std. Error of the } \\
\text { Estimate }\end{array}$ \\
\hline 1 & $0,894^{\mathrm{a}}$ & 0,799 & 0,791 & 0,26342 \\
\hline
\end{tabular}

Sumber: Data Penelitian, 2021

Hasil uji koefisien determinasi dalam penelitian ini dapat dilihat Tabel 2, menunjukan nilai determinasi sebesar 0,791 memiliki arti sebesar 79,1\% variasi Kinerja Pegawai dipengaruhi oleh variasi efektivitas penerapan sistem informasi akuntansi, teknologi informasidaninternal locus of control sedangkan sisanya 20,9\% dijelaskan oleh faktor lain yang tidak dimasukkan kedalam model.

Uji kelayakan model atau uji F digunakan untuk tahapan awal mengidentifikasikan model regresi yang dikatakan layak atau tidak layaknya pengaruh variabel bebas terhadap variabel terikat secara bersama. Sebagai. Hasil uji regresi dikatakan layak jika memiliki nilai signifikansi uji $\mathrm{F}$ kurang dari 0,05 $(=0,05)$. Hasil uji kelayakan pada model penelitian ini dapat dilihat pada tabel 4.12, sebagai berikut:.

Tabel 3. Hasil Uji F

\begin{tabular}{lllllll}
\hline Model & $\begin{array}{l}\text { Sum } \\
\text { Squares }\end{array}$ & of & $d f$ & $\begin{array}{l}\text { Mean } \\
\text { Square }\end{array}$ & $F$ & Sig. \\
\hline 1 & Regression & 19,900 & 3 & 6,633 & 95,592 & $0,000^{\mathrm{b}}$ \\
& Residual & 4,996 & 72 & 0,069 & & \\
& Total & 24,896 & 75 & & & \\
\hline
\end{tabular}

Sumber: Data Penelitian, 2021 
Hasil uji kelayakan model atau uji $\mathrm{F}$ yang telah disajikan pada Tabel 4.14, dapat dikatakan bahwa nilai $\mathrm{F}$ sebesar 95,592 dengan signifikansi sebesar 0,000. Hal tersebut menunjukan bahwa signifikansi pada uji $\mathrm{F}$ lebih kecil dari 0,05, maka berarti bahwa variabel bebas memengaruhi variabel terikat secara serempak dandapat disimpulkan bahwa model regresi pada penelitian ini layak digunakan dalam menjelaskan pengaruh efektivitas penerapan sistem informasi akuntansi, teknologi informasidaninternal locus of control pada kinerja pegawai.

Efektivitas dapat dikatakan sebagai ukuran mengenai pekerjaan yang dilakukan seberapa baik dan apakah individu tersebut mampu menghasilkan output sesuai dengan yang diharapkan (Kristiani, 2012). Efektivitas sistem dapat dilihat dari keikutsertaan dalam pembuatan keputusan, kualitas informasi, evaluasi kinerja, pengendalian intern dalam menujang transaksi (Sajady et al., 2008). Sistem informasi akuntansi ini memberikan kesempatan kepada organisasi dalam menunjang efektivitas dan efisiensi dalam pengambilan keputusan sehingga dapat meningkatkan kinerja pegawai dalam suatu instansi.

Hasil penelitian menunjukan bahwa efektivitas penerapan sistem informasi akuntansi memengaruhi positif dan signifikan pada kinerja pegawai. Artinya kinerja pegawai Inspektorat Provinsi Bali akan semakin baik apabila dalam menerapkan sistem informasi akuntansi dilakukan secara efektif dan efisien. Dengan penerapan suatu sistem informasi akuntansi dapat membantu pegawai dalam melakukan pekerjaannya secara tepat waktu, berkualitas, serta efektif dan efisien. Sejalan dengan model Technology Acceptance Model (TAM) yang menyatakan bahwa penggunaan suatu sistem informasi dipengaruhi oleh faktor kemanfaatan (perceived usefullnes) dan kemudahan pemakai (perceived ease of use). Penggunaan suatu sistem informasi akuntansi yang efektif akan memberikan manfaat yang besar dan cenderung akan digunakan dalam meningkatan kinerja pegawai Inspektorat Provinsi Bali. Hal tersebut dapat menunjang peningkatan kinerja dari pegawai itu sendiri.

Hasil penelitian ini didukung dengan penelitian sebelumnya yang dilakukan oleh (Anjani Dewantari \& Putra, 2019) yang menyatakan bahwa efektivitas penerapan sistem informasi akuntansi berpengaruh terhadap kinerja karyawan. Sejalan dengan penelitian (Sugiantara \& Putra, 2017) yang menyatakan bahwa faktor efektivitas penerapan sistem informasi akuntansi berpengaruh terhadap kinerja pegawai.

Kecanggihan suatu teknologi informasi dapat dilihat dari jumlah teknologi informasi yang digunakan, dan kompleksitas informasi yang dihasilkan. Teknologi informasi membantu pegawai dalam mencari informasi yang dibutuhkan dan mengolahnya sehingga dapat menghasilkan output yang berkualitas. Teknologi informasi ini juga bermanfaat dalam keamanan data suatu organisasi agar terhindar dari resiko terjadinya peretasan data.

Hasil penelitian menunjukan teknologi informasi memengaruhi positif pada kinerja pegawai. Artinya semakin baik teknologi informasi yang di gunakan maka kinerja pegawai pada Inspektorat Provinsi Bali tersebut semakin meningkat. Teknologi informasi ini memudahkan pengguna dalam menyelesaikan pekerjaan dengan lebih cepat, akurat, dan tepat waktu. Hal ini sejalan dengan teori TRA yang menyatahan bahwa seseorang akan melakukan sesuatu jika secara rasional hal tersebut dapat memberikan manfaat pada 
dirinya. Hal ini yang selanjtnya melandasi model TAM yang menyatakan bahwa penggunaan suatu teknologi informasi dipengaruhi oleh faktor kemanfaatan (perceived usefullnes) dan kemudahan pemakai (perceived ease of use). Adanya suatu teknologi informasi akan semakin memepermudah pengguna dan memberikan manfaat sehingga pengguna sistem akan cenderung menerima dan menggunakan teknologi informasi. Hasil penelitian ini didukung dengan penelitian sebelumnya yang dilakukan oleh (Dewi \& Dharmadiaksa, 2019)yang menyatakan bahwa kecanggihan teknologi informasi berpengaruh positif terhadap kinerja individu.

Internal Locus Of Control merupakan keyakinan seorang individu bahwa mereka memegang kendali atas peristiwa-peristiwa yang mereka alami. Keyakinan individu sendirilah yang mampu mengendalikan atau tidaknya peristiwa yang akan dihadapi. (Wang \& Newlin, 2000) individu dengan internal LOC memiliki orientasi untuk bekerja lebih baik, memiliki tingkat kepuasan kerja yang tinggi dan rata-rata kemalasan yang lebih rendah dibanding individu dengan individu yang cenderung memiliki lokus kendali eksternal.

Hasil penelitian menunjukan bahwa internal locus of control memengaruhi positif dan signifikan pada kinerja pegawai. Artinya semakin tinggi internal locus of control yang ada dalam diri pegawai, maka akan semakin meningkatkan kinerja pegawai Inspektorat Provinsi Bali. Hal ini didukung oleh teori TRA menyatakan bahwa tindakan yang dipengaruhi oleh reaksi dan persepsi seseorang terhadap suatu hal akan menentukan sikap dan perilaku orang tersebut. Reaksi dari pemakaian teknologi akan memengaruhi sikapnya dalam penerimaan teknologi tersebut. Dimana sikap pengguna teknologi ini dipengarui oleh locus of control, individu yang memiliki internal LOC memiliki orientasi untuk bekerja lebih baik, memiliki tingkat kepuasan kerja yang tinggi dan ratarata kemalasan yang lebih rendah. Internal LOC bermanfaat dalam membangun sikap pengguna menjadi lebih mudah dalam menerima suatu teknologi informasi yang berdampak pada peningkatkan kinerja pengguna sistem informasi berbasis teknologi pada Inspektorat Provinsi Bali.

Hasil penelitian ini didukung dengan penelitian sebelumnya yang dilakukan oleh (Putra \& Ratna Sari, 2018) yang menyatakan bahwa locus of control berpengaruh positif pada kinerja karyawan.

Secara teoritis penelitian ini menunjukkan bahwa tingkat efektivitas penerapan sistem informasi akuntansi, teknologi informasi, daninternal locus of control memengaruhi positif dan signifikan padakinerja pegawai dengan menggunakan Theory Reason Of Action (TRA) dan model Technology Acceptance Model (TAM). Hasil penelitian ini memberikan bukti empiris dan dapat dinyatakan mendukung hasil-hasil studi terdahulu.

Penelitian ini diharapkan bagi pegawai Inspektorat Provinsi Bali dapat lebih memerhatikan kinerja pegawainya yang dipengaruhi oleh tingkat efektivitas penerapan sistem informasi akuntansi, teknologi informasi dan, internal locus of control agar nantinya dapat berbenah ke arah yang lebih baik sehingga dapat meningkatkan kinerja pegawai. Selain itu penelitian ini juga diharapkan memberikan suatu informasi untuk penelitian selanjutnya guna untuk penyempurnaan penelitian mengenai hal sejenis. 


\section{SIMPULAN}

Efektivitas penerapan sistem informasi akuntansi berpengaruh positif dan signifikan terhadap kinerja pegawai. Teknologi informasi berpengaruh positif dan signifikan terhadap kinerja pegawai. Internal Locus Of Control berpengaruh positif dan signifikan terhadap kinerja pegawai. Pegawai pengguna SIA berbasis teknologi pada Inspektorat Provinsi Bali diharapkan mampu meningkatkan kinerjanya melalui penerapan SIA secara efektif dan meningkatkan kualitas teknologi informasi. Salah satu cara meningkatkan kinerja pegawai melalui efektifitas penerapan SIA berbasis teknologi adalah dengan menggunakan SIA secara praktis dan sesuai dengan kebutuhan serta memerbaharui penggunaan SIA berbasis teknologi secara berkala, dengan efektifnya penerapan SIA berbasis teknologi pada Inspektorat Provinsi Bali diharapkan mampu mengurangi kesalahan dalam penginputan data pada saat proses penganggran, membantu mengefisiensi waktu, biaya, dan tenaga yang dikeluarkan untuk menyelesaikan pekerjaannya, yang diharapkan dapat meminimalisir keterlambatan dalam proses penyelesaian anggaran sehingga kinerja pegawai pengguna sistem pada Inspektorat Provinsi Bali dapat meningkat.Bagi pegawai Inspektorat Provinsi Bali diharapkan dapat meningkatkan kinerja pegawai dengan mengembangkan internal locus of control yang ada dalam diri pegawai, untuk dapat memenuhi hal tersebut pimpinan sebaiknya mampu memotivasi kepada pegawai agar memiliki keyakinan terhadap tanggung jawab dalam menyelesaikan pekerjaannya. Pegawai yang bertanggung jawab akan menyelesaikan pekerjaannya dengan baik dan dapat mengatasi permasalahan dalam pekerjaannya sehingga akan berdampak pada peningkatan kinerja pegawai.

\section{REFERENSI}

Al-Eqab; Adel. (2013). The Impact of IT Sophistications on the Perceived Usefulness of Accounting Information Characteristics among Jordanian Listed Companies Mahmoud Al-Eqab College of Bussiness Adminstration Prince Sultan University Riyadh, Kingdome of Saudi Arabia College o. International Journal of Business and Social Science, 4(3), 145-155.

Alannita, N. P., \& Suaryana, I. G. N. A. (2014). Pengaruh Kecanggihan Teknologi Informasi, Partisipasi Manajemen, Dan Kemampuan Teknik Pemakai Sistem Informasi Akuntansi pada Kinerja Individu. E-Jurnal Akuntansi Universitas Udayana 6.1 (2014):33-45, 2(4), 801-810.

Anjani Dewantari, N. M. F., \& Putra, I. M. P. D. (2019). Pengaruh Efektivitas Penerapan SIA, Pemanfaatan TI, Kesesuaian Tugas, dan Keahlian Pemakai Komputer pada Kinerja Karyawan. E-Jurnal Akuntansi, 27, 644. https://doi.org/10.24843/ eja.2019.v27.i01.p24

Awosejo, O.J, Kekwaletswe, R, M, Pretorius, P and Zuva, T. (2013). The Effect of Accounting Information Systems in Accounting. International Journal of Advanced Computer Research, 1(2), 21-31.

Brownell, P. (1981). Budgeting, locus of control and organizational effectiveness. The Accounting Review, 56(4), 844-860.

Davis, F. D. (1989). Perceived usefulness, perceived ease of use, and user acceptance of information technology. MIS Quarterly: Management Information Systems, 13(3), 319-339. https:/ / doi.org/10.2307/249008 
Dewi, L. P. R., \& Dharmadiaksa, I. B. (2019). Pengaruh Efektivitas SIA, Kecanggihan Teknologi Informasi, dan Kemampuan Teknik Pemakai SIA pada Kinerja Individu. E-Jurnal Akuntansi, 27, 1735. https://doi.org/10.24843/eja.2019.v27.i03.p04

Goodhue, D. L., \& Thompson, R. L. (1995). Taming the complexity of biological pathways through parallel computing. Briefings in Bioinformatics, 10(3), 278288. https://doi.org/10.1093/bib/bbp020

Gupta, M. P., Kanungo, S., Kumar, R., \& Sahu, G. P. (2007). A study of information technology effectiveness in select government organizations in India. Vikalpa, 32(2), 7-21. https:// doi.org/10.1177/0256090920070202

Hussein. (2007). The impact of technological factors on information systems success in the electronic-government context. Business Process Management Journal, 13(5), 613-627. https:// doi.org/10.1108/14637150710823110

Imam, Z. (2012). Study of effect of accounting information systems and softwares on qualitative features of accounting information. International Journal of Management Sciences and Business Research, 1(4), 1-12.

Indralesmana, K., \& Suaryana, I. (2014). Penerapan Sistem Informasi Akuntansi Dan Kinerja Individu pada Usaha Kecil Dan Menengah Di Nusa Penida. EJurnal Akuntansi Universitas Udayana, 7(2), 345-356.

Ismail, N. A., \& King, M. (2007). Factors influencing the alignment of accounting information systems in small and medium sized Malaysian manufacturing firms. Journal of Information Systems and Small Business, 1(1-2), 1-20.

Kinarwanto, B. (2013). Faktor-faktor Pemanfaatan Teknologi Informasi dan Pengaruhnya Terhadap Kinerja Individual (Studi pada PDAM Kota Malang).

Krahel, J. P., \& Vasarhelyi, M. A. (2014). AIS as a Facilitator of Accounting Change: Technology, Practice, and Education. Journal of Information Systems, 28(2), 1-15. https:// doi.org/10.2308/isys-10412

Kristiani, W. (2012). Analisis Pengaruh Efektivitas Teknologi Sistem Informasi Terhadap Kinerja Individual Pegawai PT Kim Eng Sekuritas Indonesia. Jurnal Akuntasi Fakultas EKonomi Universitas Gunadharma.

Kusnadi, I. M. G., \& Suputhra, D. G. D. (2015). Pengaruh Profesionalisme Dan Locus of Control Terhadap Kinerja Auditor Di Kantor Akuntan Publik Provinsi Bali. E-Jurnal Akuntansi, 13(1), 276-291.

Leach-Lopez, M. (2013). Moderating Effect of Hofstede's Cultural Values on the Locus of Control/job Performance Relationship of Managers in USA, Mexico, South Korea and Hong Kong. Journal of Business Strategies, 30(1), 1.

Marjulin. (2019). Pengaruh KOmpetensi pengguna terhadap kualitas sistem informasi akuntansi survei BUMN di Aceh. Kemampuan Koneksi Matematis (Tinjauan Terhadap Pendekatan Pembelajaran Savi), 53(9), 1689-1699.

Nainggolan, M. ., Kojo, C., \& Sendow, G. (2018). Analisis Pengaruh Internal Locus of Control Dan External Locus of Control Terhadap Kepuasan Kerja Serta Dampaknya Terhadap Kinerja Ratulangi Analysisn of the Effect of Internal Locus of Control and External Locus of Control on Job Satisfaction and Its Imp. Jurnal EMBA, 6(4), 4023-4032.

Putra, D. P. A. D., \& Ratna Sari, M. M. (2018). Pengaruh Efektivitas SIA dan Komitmen Organisasi pada Kinerja Karyawan dengan Locus Of Control Sebagai Pemoderasi. E-Jurnal Akuntansi, 23, 323. 
https:// doi.org/10.24843/ eja.2018.v23.i01.p13

Putra, I. M., Gunawan, A., \& Tenaya, A. I. (2017). Pengaruh Efektivitas Sistem Informasi Akuntansi pada Kinerja Individual Dengan Kemampuan Teknik Personal Sebagai Pemoderasi. E-Jurnal Akuntansi, 20(2), 1621-1647. https://doi.org/10.24843/EJA.2017.v20.i02.p27

Rahayu, N. M. M. S., \& Badera, i D. N. (2017). Pengaruh Locus of Control Internal , Motivasi Kerja , Gaya Kepemimpinan Transformasional , Komitmen Made Mas Sendhi Rahayu 1 Fakultas Ekonomi dan Bisnis Universitas Udayana ( Unud ), Bali, Indonesia Fakultas Ekon. E-Jurnal Akuntansi Universitas Udayana, 19, 2378-2406.

Ratnaningsih, K., \& Suaryana, I. (2014). Pengaruh Kecanggihan Teknologi Informasi, Partisipasi Manajemen, Dan Pengetahuan Manajer Akuntansi pada Efektivitas Sistem Informasi Akuntansi. E-Jurnal Akuntansi, 6(1), 1-16. https://ocs.unud.ac.id/index.php/Akuntansi/article/view/7775

Rotter. (1966). Generalized Expectancies for Internal Versus External Control of Reinforcement. Psychological Monographs: General and Applied.

Sajady, H., Dastgir, M., \& Hashem Nejad, H. (2008). Evaluation of the effectiveness of accounting information systems. International Journal of Information Science and Management, 6(2), 49-59.

Salehi, M., Rostami, V., \& Mogadam, A. (2010). Usefulness of Accounting Information System in Emerging Economy: Empirical Evidence of Iran. International Journal of Economics and Finance, 2(2), 186-195. https://doi.org/10.5539/ijef.v2n2p186

Sari. (2017). Pengaruh Kecanggihan Teknologi Informasi Dan Jiwa Kewirausahaan Terhadap Kualitas Informasi Akuntansi. E-Jurnal Akuntansi, 18(2), 1635-1662.

Soudani, S. N. (2012). The Usefulness of an Accounting Information System for Effective Organizational Performance. International Journal of Economics and Finance, 4(5), 136-145. https:/ / doi.org/10.5539/ijef.v4n5p136

Sugiantara, \& Putra, I. M. P. D. (2017). Analisis Faktor-Faktor Yang Mempengaruhi Kinerja Karyawan Di Dispenda Kota Denpasar. E-Jurnal Akuntansi, 20(3), 2509-2538.

Sumardiyanti. (1999). Pengaruh Pemanfaatan Atas Kecocokan Tugas Tekologi Sistem Informasi Terhadap Pencapaian Individual. Universitas Gajah Mada.

Suratini, N. P. E., Sinarwati, N. K., \& Atmdja, A. W. T. (2015). Pengaruh Efektivitas Sistem Informasi Akutansi dan Penggunaan Teknologi Informasi Akutansi Terhadap Kinerja Individual pada PT. Bank Pembangunan Daerah Bali Kantor Cabang Singaraja. JIMAT (Jurnal Ilmiah Mahasiswa Akuntansi) Undiksha, $3(1)$. https:/ / ejournal.undiksha.ac.id/index.php/S1ak/article/view/4779/3621

Turnip, \& Suardhika. (2018). Pengaruh Kemampuan Teknik Personal, Pelatihan dan Pendidikan terhadap Efektivitas Penggunaan SIA pada Rumah Sakit. EJurnal Akuntansi, 22(2), 1419-1444. https://doi.org/10.24843/EJA.2018.v22.i02.p22

Wang, A. Y., \& Newlin, M. H. (2000). Characteristics of students who enroll and succeed in psychology web-based classes. Journal of Educational Psychology, 92(1), 137-143. https:// doi.org/10.1037/0022-0663.92.1.137 